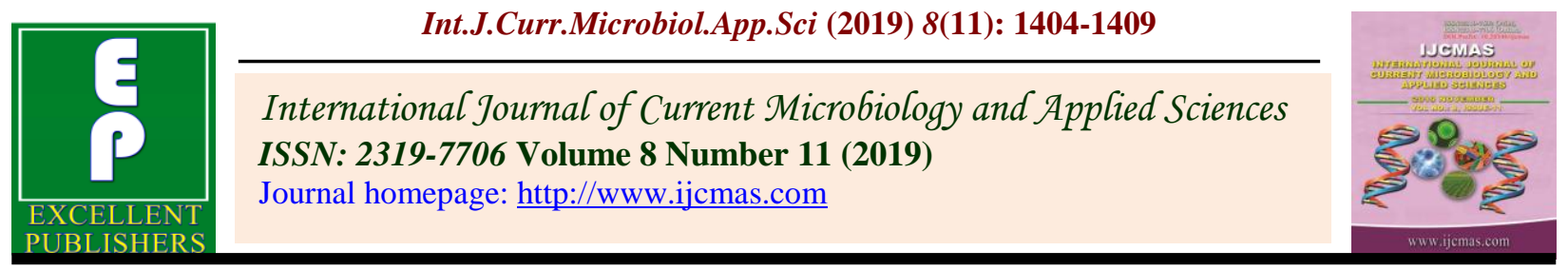

Original Research Article

https://doi.org/10.20546/ijcmas.2019.811.164

\title{
Comparative Efficiency of Whole blood and FTA Card for Diagnosis of Theileriosis in Buffaloes of Nagpur Region, India
}

\author{
Sabhyata Sharma*, S.W. Kolte, N.V. Kurkure, S.G. Jadhao and Swapnil Magar \\ Department of Veterinary Parasitology, Nagpur Veterinary College, MAFSU, Nagpur, India \\ *Corresponding author
}

\begin{tabular}{|l|}
\hline Ke y w o r d s \\
Haemaphysalis, \\
Ambylommaand \\
Rhipicephalus, \\
Theileria orientalis, \\
Haemoprotozoan
\end{tabular}

A B S T R A C T
Theileriosis is a tick borne haemoprotozoan disease caused by Theileria annulata and Theileria orientalis, mainly. The disease is known to be highly fatal and is also responsible for heavy economical loses in dairy industry. In the present study, blood samples were collected from the buffaloes suspected for theileriosis. A total of 50 blood samples from jugular vein of buffaloes were collected in EDTA tube and a drop of fresh blood was also taken on FTA card for DNA isolation. For Polymerase chain reaction, the primer sequences were used as per Kakati et al., and Kolte et al., The PCR assay employs primers specific for the gene encoding $30 \mathrm{kDa}$ major merozoite surface antigen of Theileria annulata and major piroplasm surface protein gene of Theileria orientalis. Out of total 50 blood samples, 13 were positive for Theileria annulata by both whole blood PCR and FTA card PCR whereas for Theileria orientalis, 23 were positive by whole blood PCR and 27 were found positive by FTA card PCR. It was found that diagnosis of Theileriosis by using FTA card is highly recommended as it is sensitive, less laborious, less chances of DNA degradation, easy and quickest method of diagnosis as compared to Whole blood.

\section{Introduction}

Livestock is one of the fastest growing fields of agriculture with the higher productivity from buffaloes. As the demand of food derived from animals is on rise that has led to the introduction of new technologies which included cross breeding programmes. Due to cross breeding, milk production has increased to an extent that according to 19th livestock census, India ranks first in buffalo population.
But on the other, it has led to introduction of new diseases in which theileriosis is one of the most economically important disease as it causes sudden reduction in milk yield and death in severe cases. Theileriosis, a tick borne haemoprotozoan disease of ruminants caused by parasite belonging to the genus Theileria under the sub-order Piroplasmorina (Demessie and Derso, 2015). Theileria is an obligate intracellular haemoprotozoan that infects both domestic and wild animals 
especially animals of bovidae family (OIE, 2014). The disease is transmitted by ixodid ticks of the genera Hyalomma, Haemaphysalis, Ambylomma and Rhipicephalus (Mans et al., 2015). The infected secretions remain in the salivary gland of ticks and while feeding on the host blood, the secretions are first vomited in the blood stream of the host and then the blood is sucked as a source of food by ticks.

The disease is characterised by clinical signs like sudden reduction in milk yield, enlarged lymph node, anorexia, emaciation, depression, lacrimation, salivation, corneal opacity, diarrhoea and death in non-treated cases. There are several number of species of Theileria that infect buffaloes but the most commonly encountered species in tropical areas are Theileria annulata and Theileria orientalis. Usually microscopic examination is the most common method of diagnosis but due to lack of sensitivity, new techniques were opted which included PCR, as it is reliable and species specific confirmatory diagnosis can be made easily even in low grade parasitemia.

\section{Materials and Methods}

\section{Animals}

The study was conducted on 50 buffaloes with the history of any of the following symptoms, which includes; high temperature $\left(102-105^{\circ} \mathrm{F}\right)$, swollen lymph node, reduced milk yield, emaciation, depression, anorexia, lacrimation, salivation, diarrhoea, constipation and petechial haemorrhages in eye.

\section{Blood sampling}

Blood samples were collected individually in $2 \mathrm{ml}$ of EDTA coated vials for DNA isolation, labelled and brought to the lab. A drop of fresh blood collected from jugular vein was taken on FTA card (Himedia) and were transported to lab in polythene zip lock bags as per the instructions given by manufacturer.

\section{Isolation of genomic DNA}

The DNA was isolated from whole blood and FTA card by using Favorgen Blood Genomic DNA Extraction Mini Kit and HimediaInsta DNA kit, respectively. The concentration of DNA was quantified by using Nano-drop spectrophotometer. The samples with ratio of O.D. 260/280 of 1.8 and above were selected for PCR whereas samples below the ratio 1.8 conc. were again subjected to DNA isolation. The assay employs primers specific for the gene encoding the 30-kDa major merozoite surface antigen of Theileria annulata (Kolte et al., 2017) and Major merozoite surface protein gene of Theileria orientalis (Kakati et al., 2015).

\section{Polymerase Chain Reaction (PCR)}

The assay employs primers specific (Table 1) for the gene encoding the $30-\mathrm{kDa}$ major merozoite surface antigen of Theileria annulata (Kolte et al., 2017) and Major piroplasm surface protein gene of Theileria orientalis (Kakati et al., 2015).

\section{PCR reaction components for Tams1 and MPSP gene}

The PCR reaction was set up into $25 \mu 1$ reaction containing $1 \mu \mathrm{l}$ of each Forward and Reverse primers, 12.5 $\mu 1$ Mater Mix (dNTPs, $\mathrm{MgCl} 2$, Dye and Taq DNA Polymerase), $9.5 \mu 1$ of nuclease free water and $1 \mu \mathrm{l}$ of DNA template.

\section{The cycling conditions in master gradient cycler for Tams 1 and MPSP gene}

The reaction condition for Tams 1 was initial denaturation at $95.0^{\circ} \mathrm{C}$ for 5 minutes followed by 30 cycles each consisting of individual 
cycle with $95.0^{\circ} \mathrm{C}$ (30 seconds), $55.0^{\circ} \mathrm{C}(30$ seconds), $72.0^{\circ} \mathrm{C}$ (1 min 10 seconds) with the final extension at $72.0^{\circ} \mathrm{C}$ ( 1 cycle) for 5 minutes.

The reaction condition for MPSP was initial denaturation at $98.0^{\circ} \mathrm{C}$ for 10 seconds followed by 35 cycles each consisting of individual cycle with $98.0^{\circ} \mathrm{C}$ (10 seconds), $55.0^{\circ} \mathrm{C}$ for 45 seconds, $72.0^{\circ} \mathrm{C}$ (30 seconds) with the final extension of $72.0^{\circ} \mathrm{C}$ for 2 minutes.

The PCR amplicons were then subjected to $0.8 \%$ of agarose gel electrophoresis and gel was examined under Gel documentation System (Gel Pro Analyser).

For confirmatory diagnosis, $25 \mu \mathrm{l}$ of PCR product positive for Theileria annulata and Theileria orientalis and $10 \mu \mathrm{l}$ of Tams 1 gene and MPSP gene targeting primers were first sent to Eurofins Genomics India Pvt. Ltd. Bengaluru, Karnataka, India for sequencing. The obtained sequences were trimmed, assembled and saved in Fasta format.

\section{Results and Discussion}

Out of 50 samples of buffaloes, PCR found 13 samples (26\%) positive for Theileria annulataby both whole blood PCR and FTA card PCR while for Theileria orientalis, 23 (46\%) were positive by whole blood PCR and $27(54 \%)$ by FTA card (Table 2 ).

On comparison of both the methods, it was found that $36(72 \%)$ by whole blood PCR and $40(80 \%)$ were found positive by FTA card PCR (Table 3). The present study is new and no comparison between whole blood PCR and FTA card PCR in buffaloes has been studied yet. For confirmatory diagnosis of Theileria spp., PCR product positive for Theileria annulata and Theileria orientalis were sent to Eurofins Genomics India Pvt. Ltd. Bengaluru,
Karnataka, India for sequencing. After BLAST analysis on National Centre for Biotechnology Information, the sequenced samples were found similar to Theileria annulata and Theileria orientalis, which confirmed the diagnosis.

The present study has revealed that PCR is most sensitive assay for diagnosis of Theileria annulata and Theileria orientalis due to its efficacy to detect infection in chronic and carrier stages and DNA isolation by using FTA card is highly recommended technique over whole blood for diagnosis of theileriosis as it can detect infection from a drop of fresh blood, reliable, less laborious, less amount of blood is required, less chances of DNA degradation and quick results are seen. The present study is in partial agreement with Durrani et al., (2008). They found $53.3 \%$ of positivity in buffaloes for Theileria annulata.

Similarly, Hassan et al., (2018) used FTA cards to determine the prevalence of Theileria spp. in Pakistan. Several workers like Mahmood et al., (2010), Kolte et al., (2017), Paliwal et al., (2019), Kundave et al., (2015) have performed PCR using whole blood and also reported that PCR was most sensitive tool for diagnosis of theileriosis. Partial similar observations were recorded earlier by Ali and Radwan (2011), Ghanem et al., (2013), Chaisi et al., (2013), Sudan et al., (2015) and many other authors.

The primers specific for the gene i.e. Tams1 (Theileria annulata merozoite surface protein) and MPSP (Major piroplasm surface protein) were used to detect Theileria annulata and Theileria orientalis with the amplicon size of 846bp for Theileria annulata (Fig. 1) and 776bp for Theileria orientalis (Fig. 2) was detected in blood samples. Similar primers were also used by Kolte et al., and Kakati et al., for diagnosis of Theileria annulata and Theileria orientalis, respectively. 
Table.1 Primers of different genes of Theileria

\begin{tabular}{|c|c|c|c|}
\hline Gene & Primer & $\begin{array}{c}\text { Product } \\
\text { size (bp) }\end{array}$ & Reference \\
\hline $\begin{array}{c}\text { Tams } \\
\mathbf{1}\end{array}$ & $\begin{array}{c}\text { F- 5'TACTTGAAGCTTCCATGTTGTCCAGGACCAC 3' } \\
\text { R-5'ATCTTGCTCGAGAAGGAAGTAAAGGACTGATGA 3' }\end{array}$ & 846 & $\begin{array}{c}\text { Kolte } \text { et } \\
\text { al., 2017 }\end{array}$ \\
\hline $\begin{array}{c}\text { MPS } \\
\text { P }\end{array}$ & F- 5'CTTTGCCTAGGATACTTCCT 3' & 776 & $\begin{array}{c}\text { Kakati } \text { et } \\
\text { R- 5'ACGGCAAGTGGTGAGAACT 3' }\end{array}$ \\
\hline
\end{tabular}

Table.2 Comparative efficiency of whole blood PCR and FTA card PCR positive for Theileria annulata and Theileria orientalis

\begin{tabular}{|c|c|c|c|}
\hline S.No. & Test & T.annulata & T.orientalis \\
\hline $\mathbf{1}$ & Whole blood PCR & $26 \%$ & $46 \%$ \\
\hline $\mathbf{2}$ & FTA card PCR & $26 \%$ & $54 \%$ \\
\hline
\end{tabular}

Table.3 Percent prevalence of theileriosis by Whole blood PCR and FTA card PCR in buffaloes

\begin{tabular}{|c|c|c|}
\hline S.No. & Test & Buffaloes \\
\hline $\mathbf{1}$ & Whole blood PCR & $72 \%$ \\
\hline $\mathbf{2}$ & FTA card PCR & $80 \%$ \\
\hline
\end{tabular}

Fig.1 Agarose gel electrophoresis of amplified T. annulata DNA

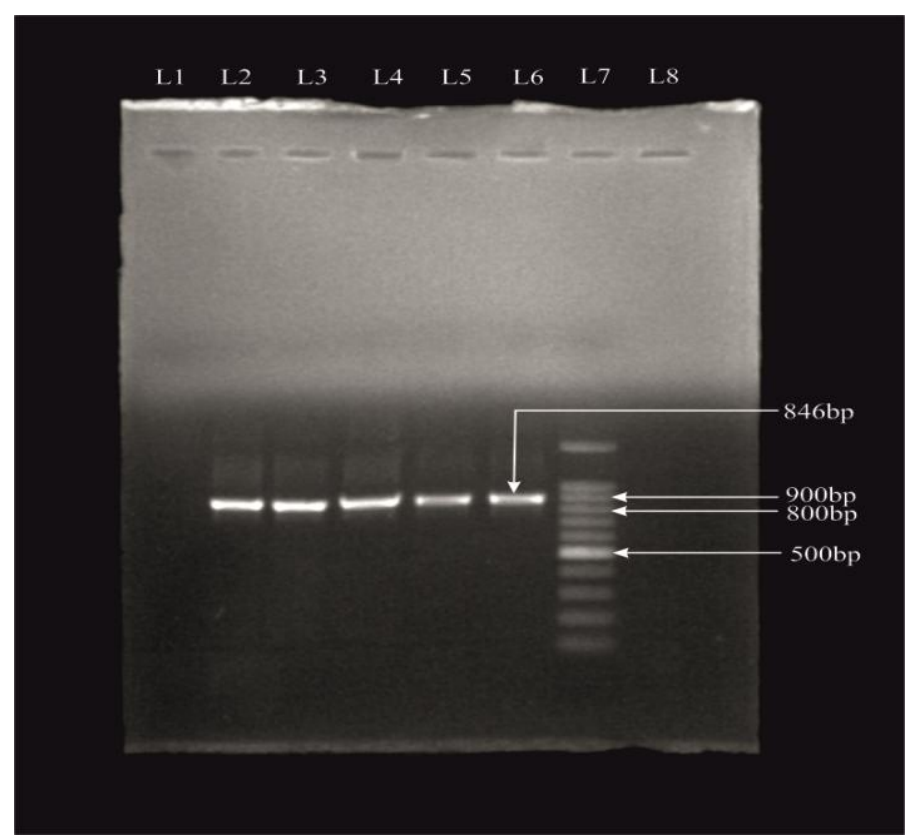

L1: Negative control, L2: Positive control, L3-L4: FTA card DNA, L5-L6: Whole blood DNA, L7: 100 bp DNA ladder 
Fig.2 Agarose gel electrophoresis of amplified T. orientalis DNA

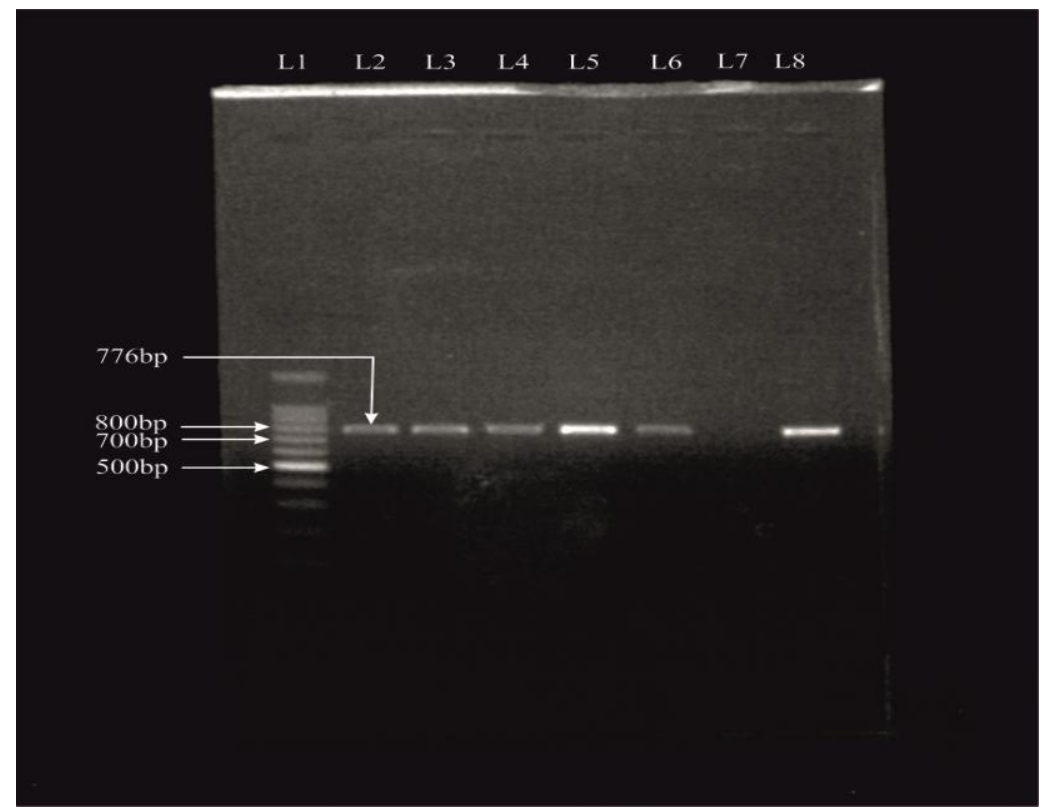

L1: DNA ladder 100 bp, L2-L4: FTA card DNA, L5-L6: Whole blood DNA, L7: Negative control, L8: Positive control

PCR is recommended as best tool for confirmatory diagnosis of Theileria annulata and Theileria orientalis as it can detect infection even in low parasitemias. DNA isolation by using FTA card is recommended over whole blood as the chances of DNA degradation is less, less laborious and diagnosis can be made quickly as compared to whole blood.

\section{References}

Ali, A. E. F and Radwan, M. E.I, 2011. Molecular detection of Theileria annulata in Egyptian Buffaloes and Biochemical changes associated with Particular oxidative changes. Advances in Life Sciences, 1(1), 6-10.

Chaisi, M. E., Janssens, M. E., Vermeiren, L., Oosthuizen, M. C., Collins, N. E., and Geysen, D. (2013). Evaluation of a real-time PCR test for the detection and discrimination of Theileria species in the African buffalo (Syncerus caffer). PloSone, 8(10), e75827.
Demessie, Y., and Derso, S. (2015). Tick borne hemoparasitic diseases of ruminants: A review. Advances in Biological Research, 9(4), 210-224.

Durrani, A. Z., Ahmad, M., Ashraf, M., Khan, M. S., Khan, J. A., Kamal, N., and Mumtaz, N. (2008). Prevalence of theileriosis in buffaloes and detection through blood smear examination and polymerase chain reaction test in district Lahore. J Anim Plant Sci, 18, 59-62.

Ghanem, M. M., Abdelhamid, O. M., and Bakir, N. M. (2013). ClinicoBiochemical, Serological and Molecular Study on Tropical Theileriosis in Egyptian Water Buffaloes (Bubalus bubalis). www. alexjvs. Com

Hassan, M. A., Liu, J., Rashid, M., Iqbal, N., Guan, G., Yin, H., and Luo, J. (2018). Molecular survey of piroplasm species from selected areas of China and Pakistan. Parasites \& vectors, 11(1), 457. 
Kakati, P., Sarmah, P. C., Ray, D., Bhattacharjee, K., Sharma, R. K., Barkalita, L. M., and Stanley, B. (2015). Emergence of oriental theileriosis in cattle and its transmission through Rhipicephalus (Boophilus) microplus in Assam, India.Veterinary world, 8(9), 1099.

Kolte, S. W., Larcombe, S. D., Jadhao, S. G., Magar, S. P., Warthi, G., Kurkure, N. V., and Shiels, B. R. (2017). PCR diagnosis of tick-borne pathogens in Maharashtra state, India indicates fitness cost associated with carrier infections is greater for crossbreed than native cattle breeds. PloS one, 12(3), e0174595.

Mahmmod, Y. S., El-Balkemy, F. A., Yuan, Z. G., El-Mekkawy, M. F., Monazie, A.M., and Zhu, X. Q. (2010). Field evaluation of PCR assays for the diagnosis of tropical theileriosis in cattle and water buffaloes in Egypt. Journal of Animal and Veterinary Advances, 9(4), 696-699.

Mans, B. J., Pienaar, R., and Latif, A. A. (2015). A review of Theileria diagnostics and epidemiology. International Journal for Parasitology: Parasites and Wildlife, 4(1), 104-118.

Office of International Des Epizooties, (2014). OIE Terrestrial Manual on Theileriosis. Chapter two, Pp.1-23.

Paliwal, S., Shanker, D., Sudan, V., Kumar, S., Srivastava, M., and Gupta, K. K. (2019). Comparison of different PCR protocols and respective primer sets from pool of TAMS 1 gene for diagnosis of calf theileriosis from semi-arid India. Biologicals, 57, 50-54.

Kundave, V. R., Patel, A. K., Patel, P. V., Hasnani, J. J., and Joshi, C. G. (2015). Detection of theileriosis in cattle and buffaloes by polymerase chain reaction. Journal of parasitic diseases, 39(3), 508-513.

Sudan, V., Jaiswal, A. K., Parashar, R., and Shanker, D. (2015). A duplex PCRbased assay for simultaneous detection of Trypanosoma evansi and Theileria annulatainfections in water buffaloes. Tropical animal health and production, 47(5), 915-919.

\section{How to cite this article:}

Sabhyata Sharma, S.W. Kolte, N.V. Kurkure, S.G. Jadhao and Swapnil Magar. 2019. Comparative Efficiency of Whole blood and FTA Card for Diagnosis of Theileriosis in Buffaloes of Nagpur Region, India. Int.J.Curr.Microbiol.App.Sci. 8(11): 1404-1409. doi: https://doi.org/10.20546/ijcmas.2019.811.164 